\title{
Desulfovibrio zosterae sp. nov., a new sulfate reducer isolated from surface-sterilized roots of the seagrass Zostera marina
}

\author{
Jens T. Nielsen, ${ }^{1}$ Werner Liesack ${ }^{2}$ and Kai Finster ${ }^{1}$ \\ Author for correspondence: Kai Finster. Tel: +458942 3241. Fax: +4586127191. \\ e-mail: kai.finster@biology.aau.dk
}

Dept of Microbial Ecology,
University of Aarhus,
Building 540, Ny
Munkegade, 8000 Århus C,
Denmark
2 Max-Planck-Institute for
Terrestrial Microbiology,
Karl von Frisch Strasse, D-
35043, Marburg, Germany

\begin{abstract}
A sulfate-reducing bacterium, designated strain lac', was isolated from surface-sterilized roots of the benthic macrophyte Zostera marina. Cells were motile by means of a single polar flagellum. Strain lac' utilized lactate, pyruvate, malate, ethanol, L-alanine, fumarate, choline and fructose with sulfate as electron acceptor. In addition, fumarate, pyruvate and fructose were also degraded without an external electron acceptor. Sulfate could be substituted with thiosulfate, sulfite and elemental sulfur. Optimal growth was observed between 32.5 and $34.5{ }^{\circ} \mathrm{C}$, at an NaCl concentration of $0.2 \mathrm{M}$ and in a pH range between 6.8 and $7 \cdot 3$. The G+C content of the DNA was $42.7 \pm 0.2 \mathrm{~mol} \%$. Desulfoviridin and catalase were present. Strain lac contained c-type cytochromes. Comparative 16S rRNA gene sequence analysis and the fatty acid pattern grouped this isolate into the genus Desulfovibrio. However, strain lac' differs from all other described Desulfovibrio species on the bases of its 165 rRNA gene sequence, the $G+C$ content, its cellular lipid pattern and the utilization pattern of substrates. These characteristics establish strain lac ${ }^{\top}$ (=DSM 11974') as a novel species of the genus Desulfovibrio, for which the name Desulfovibrio zosterae sp. nov. is proposed.
\end{abstract}

Keywords: root-associated bacteria, seagrass, Desulfovibrio zosterae sp. nov., fructose metabolism, sulfate reducer

\section{INTRODUCTION}

Sulfate-reducing bacteria have been isolated from a large number of different habitats, which has led to the conclusion that they are widespread in nature (Widdel \& Bak, 1992). Typically, sulfate-reducers are found in anoxic, marine environments where sulfate is available in excess (Widdel, 1988; Jørgensen \& Bak, 1991), but they have also been isolated from freshwater environments such as lake sediment (Bak \& Pfennig, 1991), from anaerobic digesters (Oude Elferink et al., 1995), the rumen of sheep (Howard \& Hungate, 1976) and the intestines of humans and termites (Beerens \& Romond, 1977; Gibson et al., 1988; Trinkerl et al., 1990).

Recently, we demonstrated that high sulfate-reducing activity was associated with sediment-free roots and rhizomes of the marine macrophyte Zostera marina (Blaabjerg \& Finster, 1998). We also showed that sulfate-reducing activity prevailed after surface steriliz-

The EMBL/GenBank/DDBJ accession number for the 165 rDNA sequence of strain lac $^{\top}$ (= DSM 11974') reported in this paper is $Y 18049$. ation of roots and rhizomes with hypochlorite $(1.05 \%$, $\mathrm{w} / \mathrm{v})$ for $30 \mathrm{~s}$. This finding led us to carry out the enrichment and isolation of root-cortex-inhabiting sulfate reducers.

In the present communication, we report on the enrichment, isolation and phenotypic and genotypic characterization of strain $\operatorname{lac}^{\mathrm{T}}$, a mesophilic, marine, fructose-oxidizing sulfate reducer isolated from surface-sterilized root tissue of the marine angiosperm Zostera marina.

\section{METHODS}

Source of organisms. Strain $\operatorname{lac}^{\mathrm{T}}$ was isolated from a mixed culture obtained from surface-sterilized roots of the eelgrass Zostera marina. The plants were obtained from a dense eelgrass meadow, in Løgstør Broad, Denmark. Root-surface sterility was achieved by washing sediment-free roots in a saline, $1.05 \%(\mathrm{w} / \mathrm{v})$ hypochlorite solution for $30 \mathrm{~s}$ (Blaabjerg \& Finster, 1998).

Strain $\operatorname{lac}^{\mathrm{T}}$ was isolated by repeated application of the agarshake dilution method in an iron-rich APW medium, previously described by Coates et al. (1995). Agar (1\%, 
w/w) was added to solidify the medium. Lactate $(10 \mathrm{mM})$ and sulfate $(10 \mathrm{mM})$ served as electron donor/carbon source and electron acceptor, respectively. Colonies of sulfate reducers were identified by their black colour, resulting from ferrous sulfide precipitation. Well-separated colonies were withdrawn from agar-shake tubes of the terminal positive dilution steps by using drawn, sterile Pasteur pipettes. The colonies were transferred to glass test tubes containing APW medium supplemented with $10 \mathrm{ml}$ lactate/sulfate. Six morphologically identical strains were isolated. One strain, designated strain $\operatorname{lac}^{\mathrm{T}}$, was studied in detail. Culture purity was examined in sulfate-free APW medium that was supplemented with fumarate $(5 \mathrm{mM})$, pyruvate $(5 \mathrm{mM})$, glucose $(5 \mathrm{mM})$ and $0 \cdot 1 \%(\mathrm{w} / \mathrm{w})$ yeast extract. In addition, cultures were regularly checked for purity by phase-contrast microscopy.

Desulfovibrio desulfuricans subsp. desulfuricans DSM 1926 was obtained from the Deutsche Sammlung von Mikroorganismen und Zellkulturen (DSMZ), Braunschweig, Germany, and was used as a positive control in the desulfoviridin test. Rhodococcus $\mathrm{sp}$. was obtained from our own culture collection and served as a positive control in the Gramstaining test.

Culture medium and substrates. Strain $\mathrm{lac}^{\mathrm{T}}$ was routinely cultivated in defined medium of the following composition ( $1^{-1}$ Milli-Q water): $\mathrm{NaCl}, 20.0 \mathrm{~g} ; \mathrm{MgCl}_{2} \cdot 6 \mathrm{H}_{2} \mathrm{O}, 3 \cdot 0 \mathrm{~g}$; $\mathrm{CaCl}_{2} .2 \mathrm{H}_{2} \mathrm{O}, 0 \cdot 15 \mathrm{~g} ; \mathrm{Na}_{2} \mathrm{SO}_{4}, 3 \cdot 0 \mathrm{~g} ; \mathrm{NH}_{4} \mathrm{Cl}, 0 \cdot 25 \mathrm{~g}$; $\mathrm{KH}_{2} \mathrm{PO}_{4}, 0.2 \mathrm{~g} ; \mathrm{KCl}, 0.5 \mathrm{~g}$. The medium was sterilized by autoclaving for $25 \mathrm{~min}$ and cooled under oxygen-free $\mathrm{N}_{2}$. After addition of $\mathrm{NaHCO}_{3}$ the gas phase was exchanged with a mixture of oxygen-free $\mathrm{N}_{2} / \mathrm{CO}_{2}(90 \% / 10 \%)$. The following sterile solutions were added aseptically: $\mathrm{NaHCO}_{3}$ solution $(1 \mathrm{M}), 30 \mathrm{ml} ; \mathrm{Na}_{2} \mathrm{~S} .9 \mathrm{H}_{2} \mathrm{O}$ solution $(0.2 \mathrm{M}), 7.5 \mathrm{ml}$; trace metal solution, $1 \mathrm{ml}$; vitamin solutions according to Widdel \& Bak (1992); selenite/tungstate solution $(0.02 \mathrm{mM}), 1 \mathrm{ml}$; lactate stock solution $(2 \mathrm{M}), 5 \mathrm{ml}$. The trace metal solution was prepared according to Ingvorsen \& Jørgensen (1984), all other solutions according to Widdel \& Bak (1992). The medium was distributed into $50 \mathrm{ml}$ bottles and closed with rubber-sealed, aluminium screw caps. Electron donors, carbon sources and acceptors were added from sterile stock solutions to give the concentrations desired. Most stock solutions were sterilized by autoclaving at $121^{\circ} \mathrm{C}$ for $25 \mathrm{~min}$. Elemental sulfur was heated to $114^{\circ} \mathrm{C}$ for $30 \mathrm{~min}$ three times at $24 \mathrm{~h}$ intervals. Heat-labile solutions were sterilized by filtration through sterile $0 \cdot 2 \mu \mathrm{m}$ filters.

Electron donors and acceptors tested. Electron donor/ acceptor tests were carried out in $50 \mathrm{ml}$ screw-capped bottles. Growing cultures were transferred three times into culture bottles with the respective electron donor/acceptor combination to ensure that growth was not due to residual lactate and/or sulfate from the original stock culture. Controls contained basal medium and inoculum but no additional electron donor or acceptor.

Diazotrophic growth was tested in $\mathrm{NH}_{4} \mathrm{Cl}$-free medium. The tolerance of strain $\operatorname{lac}^{\mathrm{T}}$ to oxygen was tested with cells harvested from exponentially growing cultures. The cells were washed to remove residual sulfides and inoculated into Erlenmeyer flasks containing basal sulfide-free, phosphatebuffered marine medium (composition as the standard medium, with the exception that $\mathrm{NaHCO}_{3}$ was replaced by $0.04 \mathrm{M} \mathrm{KH}_{2} \mathrm{PO}_{4}$ and $0.06 \mathrm{M} \mathrm{K}_{2} \mathrm{HPO}_{4}$ ). The flasks were closed with sterile cotton stoppers. The medium contained lactate and sulfate. The flasks were incubated on a shaker and shaken vigorously throughout the experiment. The oxygen concentration of the medium was monitored with an oxygen electrode. Cell survival was evaluated by testing subcultures for their ability to grow in anaerobic standard medium after increasing periods of oxygen exposure. The last subsample was taken after $72 \mathrm{~h}$.

Analytical procedures. Lactate, acetate, succinate, ethanol, pyruvate, fumarate and fructose were analysed by ionexclusion chromatography by using an Aminex HPX-87H column (Bio-Rad) for compound separation. $\mathrm{H}_{2} \mathrm{SO}_{4}$ $(0.05 \mathrm{mM})$ was used as eluent. The flow rate was $0.9 \mathrm{ml} \mathrm{min}{ }^{-1}$. The oven temperature was $65^{\circ} \mathrm{C}$. The injected sample volume was $100 \mu \mathrm{l}$. Fructose was quantified with a refractory index detector. All other compounds were measured with a UV-detector at $210 \mathrm{~nm}$.

Sulfate was determined by suppressed-ion chromatography as described by Isaksen \& Finster (1996).

Cellular fatty acids were analysed as described by Vainshtein et al. (1992). Cells were harvested in the late exponential growth phase by centrifugation and freeze-dried. The cellular fatty acid analysis was carried out at the DSMZ. The fatty acid nomenclature of Vainshtein et al. (1992) was used.

The $\mathrm{pH}$, salt and temperature tolerance of strain $\operatorname{lac}^{\mathrm{T}}$ was studied by growth tests in which the change in optical density (at $600 \mathrm{~nm}$ ) was monitored (using a Bausch \& Lomb Spectronic 88 spectrophotometer). Experiments were carried out in duplicate. Generation times were calculated from the increase in optical density of the culture over time.

Cytochromes were analysed by using intact, washed cells suspended in phosphate buffer $\left(1.0 \mathrm{~g} \mathrm{KH}_{2} \mathrm{PO}_{4} \mathrm{l}^{-1}\right.$ and $1.0 \mathrm{~g}$ $\mathrm{K}_{2} \mathrm{HPO}_{4} 1^{-1}, \mathrm{pH} 7 \cdot 0$ ). A dithionite-reduced minus air-oxidized difference spectrum was obtained on a Hitachi U-2000 Spectrometer. The presence of desulfoviridin was tested by treating cells with $2 \mathrm{M} \mathrm{NaOH}$ and observing a red fluorescence in light of $366 \mathrm{~nm}$ (Widdel \& Pfennig, 1984). Catalase was assayed by treating a dense cell suspension with a few drops of a $3 \% \mathrm{H}_{2} \mathrm{O}_{2}$ solution and looking for bubble formation. Intracellular polyglucose was determined with lactate-grown cells after hydrolysis in $2 \mathrm{M} \mathrm{H}_{2} \mathrm{SO}_{4}$ at $120^{\circ} \mathrm{C}$ for $20 \mathrm{~min}$, with a glucose assay kit (Sigma). The $\mathrm{G}+\mathrm{C}$ content of the DNA was determined at the DSMZ according to a standard protocol, which included methods developed by Mesbah et al. (1989), Tamaoka \& Komagata (1984) and Visuvanathan et al. (1989).

Comparative 16S rRNA gene sequence analysis. DNA isolation, PCR-mediated amplification of the 16S rRNA gene from positions 28 to 1491 (numbering according to the International Union of Biochemistry nomenclature for Escherichia coli 16S rRNA) and sequencing analysis were done as described previously by Finster et al. (1998). Phylogenetic placement of strain $\operatorname{lac}^{\mathrm{T}}$ was done by use of the ARB program package (Strunk \& Ludwig, 1996). The 16S rRNA gene sequence of strain $\operatorname{lac}^{\mathrm{T}}$ was compared with a database of about 6000 complete or partial bacterial $16 \mathrm{~S}$ rRNA gene sequences (Rodriguez-Tomé et al., 1996; Maidak et al., 1997; Van de Peer et al., 1996) by using the automatic alignment tool of the ARB program package. This

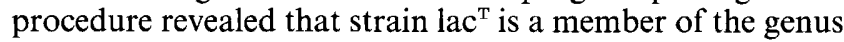
Desulfovibrio within the $\delta$-subclass of the class Proteobacteria. The phylogenetic position of strain $\operatorname{lac}^{\mathrm{T}}$ was determined in more detail by comparing its $16 \mathrm{~S}$ rRNA gene sequence with reference sequences of the family Desulfovibrionaceae and representatives of other major lineages of the $\delta$-subclass of Proteobacteria. Each of these reference sequences contained at least 1000 unambiguously determined nucleotide sequence positions. The tree topology was evaluated by using a distance matrix analysis. Only nucleo- 
tide sequence positions that contained identical nucleotides in at least $50 \%$ of $10216 \mathrm{~S}$ rRNA sequences comprising the major lineages of the $\delta$-subclass of Proteobacteria (1369 nucleotide sequence positions) were considered for phylogenetic inference. Evolutionary distance values between pairs of micro-organisms were calculated by using the Jukes-Cantor equation (Jukes \& Cantor, 1969) and only those positions present in both sequences of the respective sequence pairs. The tree was constructed by using the neighbour-joining algorithm (Saitou \& Nei, 1987).

The accession numbers of the reference sequences used for the phylogenetic assignment of strain $\operatorname{lac}^{\mathrm{T}}$ are: Desulfovibrio africanus, M37315; Desulfovibrio aespoeensis, X95230; 'Desulfovibrio bastinii', U53462; 'Desulfovibrio caledoniensis', U53465; Desulfovibrio desulfuricans, M34113; Desulfovibrio fructosovorans, AF050101; Desulfovibrio gigas, M34400; Desulfovibrio halophilus, U48243; Desulfovibrio longus, X63623; Desulfovibrio salexigens, M34401; Desulfovibrio termitidis, X87409; Desulfomicrobium baculatum, M37311; Desulfuromonas acetoxidans, M26634; Desulfurobacter postgatei, M26633; Desulfocapsa thiozymogenes, X95181; Escherichia coli, J01695; and Syntrophus buswellii, $\mathrm{X} 85131$.

\section{RESULTS}

\section{Enrichment and isolation}

A sulfate-reducing enrichment culture was obtained within $8 \mathrm{~d}$. The culture was dominated by highly motile, Desulfovibrio-type cells and developed an intense smell of hydrogen sulfide.

After transfer to agar-shake tubes, the formation of black colonies was observed within $2 \mathrm{~d}$. The black colour of the colonies indicated that they contained sulfate-reducing bacteria. Well-separated colonies were isolated from the highest dilutions and transferred to liquid medium. Direct microscopical examination of colonies withdrawn revealed that they developed around a nucleus of precipitated material. The cells were morphologically identical to those that were dominant in the enrichment culture. Six strains were obtained in pure culture. One strain, designated strain $\operatorname{lac}^{\mathrm{T}}$, was studied in detail.

\section{Cell morphology}

Cells of strain $\operatorname{lac}^{\mathrm{T}}$ were of vibrioid to sigmoid morphology. Single cells were $\sim 3.0 \mu \mathrm{m}$ long, $\sim$ $0.5 \mu \mathrm{m}$ wide and motile by means of a single polar flagellum. They often appeared in pairs. Under suboptimal conditions, cells formed corkscrew-shaped chains consisting of ten or more cells. Cells stained Gram-negative. Endospores were never observed.

\section{Physiological and biochemical characteristics}

Strain lac ${ }^{\mathrm{T}}$ grew at $\mathrm{NaCl}$ concentrations between $0 \cdot 0$ and $0.6 \mathrm{M}$. The highest growth rate $\left(0 \cdot 1 \mathrm{~h}^{-1}\right)$ was observed in the presence of $0.2 \mathrm{M} \mathrm{NaCl}$. The highest culture density was measured in an $\mathrm{NaCl}$ concentration interval of $0.4-0.6 \mathrm{M}(1.8 \times$ final culture density measured at $0.2 \mathrm{M} \mathrm{NaCl}$ ). Growth occurred in media without added $\mathrm{NaCl}$.
Strain $\operatorname{lac}^{\mathrm{T}}$ grew between 5 and $34.5^{\circ} \mathrm{C}$. The growth optimum was between 32.5 and $34.5^{\circ} \mathrm{C}$. Strain lac $^{\mathrm{T}}$ had the shortest lag phase in the temperature interval $21.5-27.5^{\circ} \mathrm{C}$ and the highest final culture density at $21.5^{\circ} \mathrm{C}$. The $\mathrm{pH}$ range in which growth occurred was 5.5-7.5 and the optimum was between $\mathrm{pH} 6.8$ and 7.3 .

The isolate used sulfate $(20 \mathrm{mM})$, thiosulfate $(20 \mathrm{mM})$, sulfite $(5 \mathrm{mM})$ and elemental sulfur as electron acceptors with lactate $(10 \mathrm{mM})$ as electron donor. The culture did not grow with nitrate ( 1 or $10 \mathrm{mM})$, nitrite (1 or $10 \mathrm{mM})$, ferrihydrite $(10 \mathrm{mM})$ or manganese oxide $(10 \mathrm{mM})$ as electron acceptors. Lactate $(10 \mathrm{mM})$, pyruvate $(10 \mathrm{mM})$, malate $(10 \mathrm{mM})$, ethanol $(10 \mathrm{mM})$, L-alanine $(10 \mathrm{mM})$, fumarate $(10 \mathrm{mM})$, fructose $(10 \mathrm{mM})$ and choline $(5 \mathrm{mM})$ served as energy and carbon sources when sulfate was present as electron acceptor. Weak growth was observed with formate plus acetate. Growth with molecular hydrogen required an organic carbon source, e.g. acetate. Fumarate $(10 \mathrm{mM})$, pyruvate $(10 \mathrm{mM})$ and fructose $(10 \mathrm{mM})$ were utilized in the absence of an external electron acceptor. Compounds tested but not utilized with or without sulfate were: acetate $(10 \mathrm{mM})$, propionate $(10 \mathrm{mM})$, butyrate $(10 \mathrm{mM})$, pentanoate $(10 \mathrm{mM})$, hexanoate $(10 \mathrm{mM})$, benzoate $(0.8$ or $10 \mathrm{mM})$, succinate $(10 \mathrm{mM})$, L-proline $(10 \mathrm{mM})$, Llysine $(10 \mathrm{mM})$, L-threonine $(10 \mathrm{mM})$, methanol $(4$ or $10 \mathrm{mM})$, isopropanol $(10 \mathrm{mM}), \quad \mathrm{D}-(+)$-mannitol $(10 \mathrm{mM})$, catechol $(0.8$ or $5 \mathrm{mM})$, phenol $(0.8$ or $5 \mathrm{mM})$, pimelate $(5 \mathrm{mM})$, betaine $(5$ or $10 \mathrm{mM})$, glyoxylate $(10 \mathrm{mM})$, nicotinate $(10 \mathrm{mM})$, acetone $(5 \mathrm{mM})$, citrate $(10 \mathrm{mM})$, furfural $(0.8$ or $5 \mathrm{mM})$, D$(+)$-mannose $(10 \mathrm{mM})$, $\mathrm{D}-(+)$-galactose $(10 \mathrm{mM})$, starch $\left(1 \mathrm{mg} \mathrm{ml}^{-1}\right)$, maltose $(10 \mathrm{mM})$, glucose $(10 \mathrm{mM})$ and saccharose $(10 \mathrm{mM})$.

Strain lac ${ }^{\mathrm{T}}$ grew diazotrophically in $\mathrm{NH}_{4} \mathrm{Cl}$-free medium for an unlimited number of transfers with lactate, pyruvate, ethanol, malate and fructose. Diazotrophic growth did not occur with $\mathrm{H}_{2}$ plus acetate and fumarate in the presence of sulfate nor with fumarate in sulfate-free medium. Culturable cells of strain $\mathrm{lac}^{\mathrm{T}}$ were retrieved after $72 \mathrm{~h}$ under atmospheric oxygen.

\section{Lactate and fructose metabolism}

Lactate was incompletely oxidized to acetate in the presence of sulfate. One mole of acetate was formed from 1 mol lactate. Fructose was incompletely oxidized to $2 \mathrm{~mol}$ acetate in the presence of sulfate. No other organic end-products were detected. A total of $20.6 \mathrm{~g}$ biomass was produced per mole fructose, giving a growth efficiency of approximately $11 \%$. The following equation for fructose oxidation is proposed:

$$
\mathrm{C}_{6} \mathrm{H}_{12} \mathrm{O}_{6}+\mathrm{SO}_{4}^{2-} \rightarrow 2 \mathrm{C}_{2} \mathrm{H}_{3} \mathrm{O}_{2}^{-}+2 \mathrm{CO}_{2}+2 \mathrm{H}_{2} \mathrm{O}+\mathrm{H}_{2} \mathrm{~S}
$$

\section{Pigments}

The difference spectrum of whole cells had optima at $421.5,524.0$ and $552.5 \mathrm{~nm}$. These peaks are charac- 
Table 1. Comparison of the properties of strain $\operatorname{lac}^{\top}$ and three other sugar-utilizing sulfate reducers belonging to the genus Desulfovibrio

$+/$ - indicates discrepancies in substrate utilization as reported by Widdel \& Pfennig (1984) and Zellner et al. (1989). (+) indicates weak growth. ND, Not determined.

\begin{tabular}{|c|c|c|c|c|}
\hline Character & Strain lac ${ }^{T}$ & $\begin{array}{c}\text { D. salexigens } \\
{\text { DSM } 2638^{\mathrm{T}}}^{\text {DS }}\end{array}$ & D. fructosovorans & D. termitidis \\
\hline \multicolumn{5}{|c|}{$\begin{array}{l}\text { Growth on, in the presence } \\
\text { of sulfate: }\end{array}$} \\
\hline Lactate & + & + & + & + \\
\hline Pyruvate & + & + & + & + \\
\hline $\mathrm{H}_{2}+\mathrm{CO}_{2}$ & - & + & - & - \\
\hline $\mathrm{H}_{2}+$ acetate $+\mathrm{CO}_{2}$ & + & + & + & - \\
\hline Formate & - & + & - & + \\
\hline Formate + acetate & $(+)$ & ND & + & \\
\hline Fumarate & + & + & + & ND \\
\hline Malate & + & + & + & - \\
\hline Alanine & + & + & - & ND \\
\hline Choline & + & $+1-$ & - & - \\
\hline Methanol & - & + & $(+)^{*}$ & ND \\
\hline Methanol + acetate & - & ND & ND & ND \\
\hline Ethanol & + & + & + & ND \\
\hline 1-Propanol & - & + & ND & ND \\
\hline Glycerol & ND & + & + & ND \\
\hline Fructose & + & ND & + & + \\
\hline Rhamnose & ND & ND & - & + \\
\hline Mannose & - & ND & - & + \\
\hline Galactose & - & ND & - & + \\
\hline Xylose & ND & ND & - & + \\
\hline Glucose & - & + & - & + \\
\hline Succinate & - & + & - & - \\
\hline Citrate & - & + & ND & ND \\
\hline \multicolumn{5}{|l|}{ Fermentation of: } \\
\hline Fructose & + & ND & + & ND \\
\hline Pyruvate & + & - & + & + \\
\hline Fumarate & + & - & + & ND \\
\hline \multicolumn{5}{|l|}{ Electron acceptors: } \\
\hline Sulfate & + & + & + & + \\
\hline Sulfite & + & ND & + & + \\
\hline Thiosulfate & + & ND & + & + \\
\hline Elemental sulfur & + & ND & + & + \\
\hline Nitrate & - & - & - & + \\
\hline \multicolumn{5}{|l|}{ Growth temperature: } \\
\hline Optimum $\left({ }^{\circ} \mathrm{C}\right)$ & $32 \cdot 5-34 \cdot 5$ & $34-37$ & 35 & 35 \\
\hline Maximum $\left({ }^{\circ} \mathrm{C}\right)$ & $34 \cdot 5$ & $42-45$ & $42-45$ & 45 \\
\hline $\mathrm{G}+\mathrm{C}$ content $(\mathrm{mol} \%)$ & 43 & 46 & 64 & $67-68$ \\
\hline
\end{tabular}

*Growth observed after pre-incubation with pyruvate.

teristic of $c$-type cytochromes. Desulfoviridin was present. Catalase was present. Polyglucose was not detected.

\section{Cellular fatty acid analysis}

The cellular fatty acid compositions of strain $\operatorname{lac}^{\mathrm{T}}$ and Desulfovibrio salexigens (Vainshtein et al., 1992) are given in Table 1. Unbranched fatty acids accounted for
$57 \%$ of the total fatty acids, with $16: 0(27 \cdot 2 \%)$ and 16 : 1 cis $9(17.3 \%)$ predominating. Forty-five per cent of the total fatty acids were monounsaturated, $16: 1$ cis $9(17 \cdot 3 \%)$ predominating.

\section{$\mathbf{G}+\mathbf{C}$ content}

The $\mathrm{G}+\mathrm{C}$ content of DNA of strain $\operatorname{lac}^{\mathrm{T}}$ was $42 \cdot 7 \pm 0 \cdot 2$ mol \% (mean value of three determinations). 


\section{Phylogeny}

Strain $\operatorname{lac}^{\mathrm{T}}$ is a member of the genus Desulfovibrio within the $\delta$-subclass of the class Proteobacteria and most closely related to Desulfovibrio salexigens. The overall identity of their 16S rRNA gene sequences was $95.9 \%$ (based on the comparison of 1291 nucleotide sequence positions). The next most-closely related organism is 'Desulfovibrio bastinii' strain SEBR4225, with an overall $16 \mathrm{~S} \mathrm{rDNA}$ identity of $92.5 \%$ (based on the comparison of 1450 nucleotide sequence positions).

\section{DISCUSSION}

Here we report the isolation of a sulfate-reducing bacterium from surface-sterilized roots of the submerged marine macrophyte Zostera marina. Due to its genotypic and phenotypic characteristics, strain lac $^{\mathrm{T}}$ was placed into the genus Desulfovibrio. Comparative 16S rDNA sequence analysis identified Desulfovibrio salexigens as its closest validly described relative (Fig. 1).

Like numerous other members of the genus Desulfovibrio, strain lac $^{\mathrm{T}}$ grew by the oxidation of lactate, pyruvate, ethanol, malate and fumarate. With lactate and fructose, incomplete oxidation to acetate and $\mathrm{CO}_{2}$ was demonstrated. Lithotrophic growth with hydrogen required an organic carbon source, e.g. acetate. Interestingly, strain lac $^{\mathrm{T}}$ grew with fructose as a carbon and energy source with or without sulfate. Sugar metabolism has rarely been described among species of sulfate reducers and, apart from some Desulfotomaculum species (Klemps et al., 1985; Daumas et al., 1988), only some members of the genus Desulfovibrio

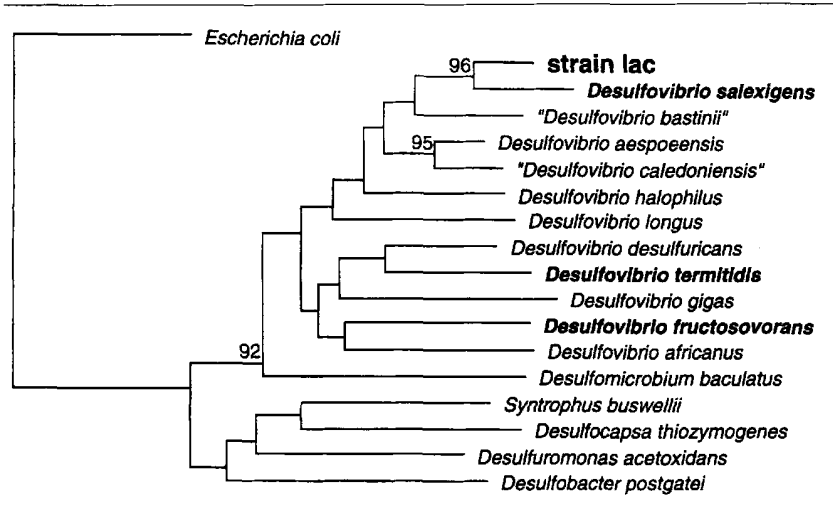

0.10

Fig. 1. Dendrogram based on 165 rRNA sequences showing the phylogenetic position of strain $\operatorname{lac}^{\top}$ in relation to other members of the family Desulfovibrionaceae and representatives of other major lineages of the $\delta$-subclass of Proteobacteria. The numbers indicate statistical significance (percentage of outcome) of the respective interior nodes in a bootstrap analysis based on 1000 neighbour-joining tests (only values above $90 \%$ are shown). The strains highlighted in bold are compared phenotypically in Table 1 . The $16 \mathrm{~S}$ rRNA sequence of Escherichia coli was used as an outgroup reference. The scale bar represents $10 \%$ estimated difference in nucleotide sequences.
Table 2. Fatty acid percentage profiles of strain $\operatorname{lac}^{\top}$ and Desulfovibrio salexigens

\begin{tabular}{|lcc|}
\hline Fatty acid & Strain lac $^{\mathbf{T}}$ & D. salexigens \\
\hline $11: 0$ & $0 \cdot 1$ & - \\
$13: 0$ iso & - & $0 \cdot 1$ \\
$14: 0$ & $0 \cdot 7$ & $1 \cdot 0$ \\
$15: 1$ iso & - & $0 \cdot 4$ \\
$15: 0$ iso & $5 \cdot 6$ & $15 \cdot 8$ \\
$15: 0$ anteiso & $10 \cdot 5$ & $4 \cdot 8$ \\
$15: 0$ & $0 \cdot 5$ & - \\
$16: 1$ iso H & $2 \cdot 2$ & $0 \cdot 3$ \\
$16: 0$ iso & $1 \cdot 4$ & $0 \cdot 3$ \\
$16: 1$ cis 9 & $17 \cdot 3$ & $9 \cdot 8$ \\
$16: 1$ cis 11 & $0 \cdot 3$ & - \\
$16: 0$ & $27 \cdot 2$ & $21 \cdot 6$ \\
$15: 0$ iso 3-OH & - & $0 \cdot 1$ \\
$17: 1$ iso C & $8 \cdot 7$ & $25 \cdot 5$ \\
$16: 0$ DMA & - & $0 \cdot 9$ \\
$17: 1$ anteiso C & $8 \cdot 3$ & $4 \cdot 0$ \\
$17: 0$ iso & $3 \cdot 0$ & $5 \cdot 4$ \\
$17: 0$ anteiso & $2 \cdot 1$ & $1 \cdot 7$ \\
$17: 0$ & $0 \cdot 5$ & - \\
$17: 0$ DMA & $0 \cdot 4$ & - \\
$16: 0$ 3-OH & $0 \cdot 4$ & $0 \cdot 1$ \\
$18: 1$ cis 9 & $0 \cdot 6$ & $0 \cdot 3$ \\
$18: 1$ cis $11 /$ trans $9 /$ trans6 & $8 \cdot 5$ & 5.1 \\
$18: 0$ & $1 \cdot 9$ & $1 \cdot 4$ \\
$17: 0$ iso 3-OH & $0 \cdot 2$ & - \\
Sum & $100 \cdot 1$ & $98 \cdot 9$ \\
\hline
\end{tabular}

—, Not detected; DMA, dimethylacetal.

have been shown to utilize these compounds (Hansen, 1993). Desulfovibrio species that have been tested positive with respect to sugar oxidation are, in addition to strain lac ${ }^{\mathrm{T}}$, Desulfovibrio fructosovorans (Ollivier $e t$ al., 1988), Desulfovibrio salexigens (Zellner et al., 1989) and Desulfovibrio termitidis (Trinkerl et al., 1990) (for detailed comparison see Table 1).

The cellular fatty acid pattern of strain $\operatorname{lac}^{\mathrm{T}}$ also supported an affiliation of this strain with the genus Desulfovibrio. As in most species of this genus, significant amounts of iso-17:1 [which was pinpointed as a biomarker for the genus Desulfovibrio (Taylor \& Parkes, 1985)], iso-15:0 and 16:0 were present in strain $\operatorname{lac}^{\mathrm{T}}$. In addition, the fatty acid pattern of strain $\mathrm{lac}^{\mathrm{T}}$ clearly distinguished it from its closest relative, Desulfovibrio salexigens (Table 2). While in Desulfovibrio salexigens iso- $15: 0$ predominated $(15 \cdot 8 \%$ versus $5.6 \%$ in strain lac $^{\mathrm{T}}$ ), anteiso-15:0 dominated in strain $\operatorname{lac}^{\mathrm{T}}$ (10.5\% versus $4.8 \%$ in Desulfovibrio salexigens). $16: 1$ cis 9 accounted for $17.3 \%$ of the cellular fatty acids in strain lac $^{\mathrm{T}}$ and for $9.8 \%$ in Desulfovibrio salexigens. The biomarker iso-17:1 was three times more abundant in Desulfovibrio salexigens than in strain $\operatorname{lac}^{\mathrm{T}}(25.5 \%$ in Desulfovibrio salexigens versus $8.7 \%$ in strain $\operatorname{lac}^{\mathrm{T}}$ ). In addition, the fatty acids $11: 0$ $(0 \cdot 1 \%), 16: 1$ cis $11(0.3 \%), 17: 0(0.5 \%), 17: 0$ DMA 
$(0.4 \%)$ and $17: 0$ iso $3-\mathrm{OH}$ were present in strain $1 \mathrm{ac}^{\mathrm{T}}$ but not in Desulfovibrio salexigens.

In contrast to Desulfovibrio salexigens, strain $\operatorname{lac}^{\mathrm{T}}$ oxidized choline and grew fermentatively with pyruvate and fructose and oxidized fructose with sulfate as electron acceptor.

On the basis of the physiological traits and the phylogenetic position, strain lac $^{\mathrm{T}}$ (= DSM 11974 $)$ may be regarded as the type strain of a new species, for which we propose the name Desulfovibrio zosterae sp. nov.

\section{Description of Desulfovibrio zosterae sp. nov.}

Desulfovibrio zosterae (zo.ste.ra'e. N.L. bot. n. zostera; N.L. gen. n. zosterae denoting that the bacterium was isolated from the plant Zostera marina). Curved rods to sigmoid-shaped cells, motile by a single polar flagellum, $\sim 3.0 \mu \mathrm{m}$ long and $\sim 0.5 \mu \mathrm{m}$ wide, normally occurring singly or in pairs. Cells stain Gramnegative and no spores were observed. The optimum $\mathrm{pH}$ is $6.8-7.3$ and the optimum temperature is between 32.5 and $34.5{ }^{\circ} \mathrm{C}$. Optimal growth at $0.2 \mathrm{M} \mathrm{NaCl}$. In the presence of sulfate, hydrogen plus acetate, lactate, pyruvate, fumarate, malate, ethanol, L-alanine, choline and fructose serve as growth substrates. Fermentative growth is possible on pyruvate, fumarate and fructose. Sulfate, thiosulfate, sulfite and elemental sulfur are utilized as electron acceptors. Oxidation of lactate and fructose with sulfate is incomplete with acetate as the end product. Grows diazotrophically. Desulfoviridin and $c$-type cytochrome are present. Catalase is present. Aerotolerant. The $\mathrm{G}+\mathrm{C}$ content of the DNA is 42.7 mol\%. Habitat is roots of the marine macrophyte Zostera marina. The type strain is strain $\operatorname{lac}^{\mathrm{T}}$ (= DSM $\left.11974^{\mathrm{T}}\right)$.

\section{ACKNOWLEDGEMENTS}

We thank Peder Hjuler for help with the Latin grammar. This work is a contribution to the ELOISE Programme (ELOISE No. 039) in the framework of the ROBUST project carried out under contract ENV4-CT96-0218. The study was supported by the Bundesministerium für Bildung, Wissenschaft, Forschung und Technologie (BMBF, contract 0311121).

\section{REFERENCES}

Bak, F. \& Pfennig, N. (1991). Sulfate-reducing bacteria in littoral sediment of Lake Constance. FEMS Microbiol Ecol 85, 43-52.

Beerens, H. \& Romond, C. (1977). Sulfate-reducing anaerobic bacteria from human feces. Am J Clin Nutr 30, 1770-1776.

Blaabjerg, V. \& Finster, K. (1998). Sulphate reduction associated with roots and rhizomes of the marine macrophyte Zostera marina. Aquat Microb Ecol 15, 311-314.

Coates, J. D., Lonergan, D. J., Philips, E. J. P., Jenter, H. \& Lovley, D. R. (1995). Desulfuromonas palmitatis sp. nov., a marine dissimilatory $\mathrm{Fe}(\mathrm{III})$ reducer that can oxidize long-chain fatty acids. Arch Microbiol 164, 406-413.

Daumas, S., Cord-Ruwisch, R. \& Garcia, J. L. (1988). Desulfotomaculum geothermicum sp. nov., a thermophilic, fatty acid- degrading, sulfate-reducing bacterium isolated with $\mathrm{H}_{2}$ from geothermal ground water. Antonie Leeuwenhoek 54, 165-178.

Finster, K., Liesack, w. \& Thamdrup, B. (1998). Elemental sulfur and thiosulfate disproportionation by Desulfocapsa sulfoexigens sp. nov., a new anaerobic bacterium isolated from marine surface sediment. Appl Environ Microbiol 64, 119-125.

Gibson, G. R., Macfarlane, G. T. \& Cummings, J. H. (1988). Occurrence of sulphate-reducing bacteria in human faeces and the relationship of dissimilatory sulphate reduction to methanogenesis in the large gut. $J$ Appl Bacteriol 65, 103-111.

Hansen, T. A. (1993). Carbon metabolism of sulfate-reducing bacteria. In The Sulfate-Reducing Bacteria: Contemporary Perspectives, pp. 21-40. Edited by J. M. Odom \& R. Singleton, Jr. New York: Springer.

Howard, B. H. \& Hungate, R. E. (1976). Desulfovibrio of the sheep rumen. Appl Environ Microbiol 32, 598-602.

Ingvorsen, K. \& Jørgensen, B. B. (1984). Kinetics of sulfate uptake by freshwater and marine species of Desulfovibrio. Arch Microbiol 139, 61-66.

Isaksen, M. F. \& Finster, K. (1996). Sulphate reduction in the root zone of the seagrass Zostera noltii on the tidal flats of a coastal lagoon (Arcachon, France). Mar Ecol Prog Ser 137, 187-194.

Jørgensen, B. B. \& Bak, F. (1991). Pathways and microbiology of thiosulfate transformations and sulfate reduction in a marine sediment (Kattegat, Denmark). Appl Environ Microbiol 57, 847-856.

Jukes, T. H. \& Cantor, C. R. (1969). Evolution of protein molecules. In Mammalian Protein Metabolism, pp. 21-132. Edited by H. N. Munro. New York: Academic Press.

Klemps, R., Cypionka, H., Widdel, F. \& Pfennig, N. (1985). Growth with hydrogen, and further physiological characteristics of Desulfotomaculum species. Arch Microbiol 143, 203-208.

Maidak, B. L., Olsen, G. J., Larsen, N., Overbeek, R., McCaughey, M. J. \& Woese, C. R. (1997). The RDP (Ribosomal Database Project). Nucleic Acids Res 25, 109-111

Mesbah, M., Premachandran, U. \& Whitman, W. B. (1989). Precise measurement of the $\mathrm{G}+\mathrm{C}$ content of deoxyribonucleic acid by high-performance liquid chromatography. Int J Syst Bacteriol 39, 159-167.

Ollivier, B., Cord-Ruwisch, R., Hatchikian, E. C. \& Garcia, J. L. (1988). Characterization of Desulfovibrio fructosovorans $\mathrm{sp}$. nov. Arch Microbiol 149, 447-450.

Oude Elferink, S. J. W. H., Maas, R. N., Harmsen, H. J. M. \& Stams, A. J. M. (1995). Desulforhabdus amnigenus gen. nov. sp. nov., a sulfate reducer isolated from anaerobic granular sludge. Arch Microbiol 164, 119-124.

Rodriguez-Tomé, P., Stoehr, P. J., Cameron, G. N. \& Flores, T. P. (1996). The European Bioinformatics Institute (EBI) databases. Nucleic Acids Res 24, 6-12.

Saitou, N. \& Nei, M. (1987). The neighbor-joining method: a new method for reconstructing phylogenetic trees. Mol Biol Evol 4 , 406-425.

Strunk, O. \& Ludwig, W. (1996). ARB : a software environment for sequence data. Technische Universität München, Munich, Germany.

Tamaoka, J. \& Komagata, K. (1984). Determination of DNA base composition by reversed-phase high-performance liquid chromatography. FEMS Microbiol Lett 25, 125-128.

Taylor, J. \& Parkes, R. J. (1985). Identifying different populations of sulphate-reducing bacteria within marine sediment systems, using fatty acid biomarkers. J Gen Microbiol 131, 631-642. 
Trinkerl, M., Breunig, A., Schauder, R. \& König, H. (1990). Desulfovibrio termitidis sp. nov., a carbohydrate-degrading sulfate-reducing bacterium from the hindgut of a termite. Syst Appl Microbiol 13, 372-377.

Vainshtein, M., Hippe, H. \& Kroppenstedt, R. M. (1992). Cellular fatty acid composition of Desulfovibrio species and its use in classification of sulfate-reducing bacteria. Syst Appl Microbiol 15, 554-566.

Van de Peer, Y., Nicolaï, S., De Rijk, P. \& De Wachter, R. (1996). Database on the structure of small ribosomal subunit RNA. Nucleic Acids Res 24, 86-91.

Visuvanathan, S., Moss, M. T., Stanford, J. L., Hermon-Taylor, J. \& McFadden, J. J. (1989). Simple enzymatic method for isolation of DNA from diverse bacteria. J Microbiol Methods 10, 59-64.
Widdel, F. (1988). Microbiology and ecology of sulfate- and sulfur-reducing bacteria. In Biology of Anaerobic Microorganisms, pp. 477-481. Edited by A. J. B. Zehnder. New York: John Wiley.

Widdel, F. \& Bak, F. (1992). The Prokaryotes, 2nd edn, pp. 3352-3378. Edited by A. Balows, H. G. Trüper, M. Dworkin, W. Harper and K.-H. Schleifer. New York: Springer Verlag.

Widdel, F. \& Pfennig, N. (1984). Dissimilatory sulfate- or sulphurreducing bacteria. In Bergey's Manual of Systematic Bacteriology, vol. 1, pp. 663-679. Edited by N. R. Krieg \& J. G. Holt. Baltimore: Williams \& Wilkins.

Zellner, G., Messner, P., Kneifel, H. \& Winter, J. (1989). Desulfovibrio simplex $\mathrm{sp}$. nov., a sulfate-reducing bacterium from a sour whey digester. Arch Microbiol 152, 329-334. 